\title{
Effectiveness of Levonorgestrel - Releasing Intrauterine System in Perimenopausal Bleeding
}

\author{
FLAVIUS OLARU1', CONSTANTIN OLARU1*, VIVIANA OLARU², LAURA NUSSBAUM3*, LAVINIA HOGEA ${ }^{3}$, ROXANA FOLESCU*, \\ MIRELA GRIGORAS ${ }^{4}$, ALINA MIHAELA PASCU ${ }^{5}$, VLADIMIR POROCH ${ }^{6,7}{ }^{\text {, }}$ DRAGOS ERDELEAN ${ }^{1}$ \\ ${ }^{1}$ Victor Babes University of Medicine and Pharmacy, Department of Obstetrics and Gynecology, Dr. D. Popescu Hospital, 2 \\ Eftimie Murgu Sq., 300041, Timisoara, Romania \\ ${ }^{2}$ Victor Babes University of Medicine and Pharmacy, Department of Plastic and Reparatory Surgery, SCJUT, 2 Eftimie Murgu Sq., \\ 300041, Timisoara, Romania \\ ${ }^{3}$ Victor Babes University of Medicine and Pharmacy, Department of Neurosciences, 2 Eftimie Murgu Sq., 300041, Timisoara, \\ Romania \\ ${ }^{4}$ Victor Babes University of Medicine and Pharmacy, Department of Anatomy and Embryology, 2 Eftimie Murgu Sq., 300041 \\ Timisoara, Romania \\ ${ }^{5}$ Transilvania University of Brasov, Faculty of Medicine, 29 Eroilor Blvd, 500036, Brasov, Romania \\ ${ }^{6}$ Grigore T. Popa University of Medicine and Pharmacy, Faculty of Medicine, 16 Universitatii Str., 700115, lasi, Romania \\ ${ }^{7}$ Regional Institute of Oncology, 2-4 G-ral Berthelot Str., 700483, Iasi, Romania
}

The study aimed to compare the effectiveness of conservative methods [ Levonorgestrel $\left(\mathrm{C}_{21} \mathrm{H}_{28} \mathrm{O}_{2}\right)$ - releasing intrauterine system $(52 \mathrm{mg})$, endometrial ablation, hysteroscopy] vs. hysterectomy in perimenopausal bleeding. The study population was represented by 270 women addressed to Genesiun Clinic between 2010-2018 for perimenopausal bleeding because of different pathological circumstances: endometrial hypertrophy, polyps, uterine fibroids, endocervical lesions, chronic endometritis, intrauterine device (IUD)related pathology, congenital abnormalities. The hysteroscopy is considered the method of choice in the diagnosis/therapeutic management of hemorrhagic metropathy. The hysteroscopic surgery was superior to hysterectomy, taking into account the postoperative complications and recovery, resumption of sexual activity and working. Levonorgestrel-releasing IUS $52 \mathrm{mg}$ proved safe and efficient in treating metrorrhagia associated with endometrial dysplasia, uterine fibroids, and polyps. The bipolar electrosurgical VERSAPOINT system demonstrated good results in the treatment of intrauterine pathology. Our results pointed out the alternative of a surgery a few months after the hysteroscopy and endometrial ablation, and also the possibility of repeating the hysteroscopy procedure after a while, in some cases. Keywords: hysteroscopy, intrauterine device (IUD), Levonorgestrel $\left(\mathrm{C}_{21} \mathrm{H}_{28} \mathrm{O}_{2}\right)$, menorrhagia, perimenopausal
bleeding

Menorrhagia is a frequent reason for women to seek medical care, representing an increasingly common health problem.

The Levonorgestrel (LNG) $\left(\mathrm{C}_{21} \mathrm{H}_{28} \mathrm{O}_{2}\right)$ - releasing intrauterine system (IUS) is an effective medical treatment option for menorrhagia. Emerging clinical and research evidence suggests that this new treatment method has major health benefits [1-3].

The quality of life improves significantly being comparable to that gained by hysterectomy [4-8].

The costs are about half of those of hysterectomy after 1 year of follow-up. Unscheduled breakthrough bleeding is the most common side effect of the treatment. There are different new theories about the mechanism underlying this problem. Women with endometriosis or fibroids also benefit from this treatment [9-12].

Because menorrhagia is often a reason for seeking medical attention, it is important to consider the outcomes and costs in order to provide the most appropriate care.

The LNG $\left(\mathrm{C}_{21} \mathrm{H}_{28} \mathrm{O}_{2}\right)$-releasing IUS improves healthrelated quality of life significantly at relatively low cost. It is the most effective medical treatment for menorrhagia, comparable to surgical interventions. Although not all women are successfully treated, about $60 \%$ avoid hysterectomy and are satisfied with the treatment. Thus, the LNG $\left(\mathrm{C}_{2} \mathrm{H}_{2} \mathrm{O}_{2}\right)$-releasing IUS should be the first line treatment for heavy menstrual bleeding, as the system is not associated with serious complications [13-16].
Although hysterectomy has been considered as the golden standard treatment choice for menorrhagia, 50\% of referrals to hospital ending to hysterectomy, the risk of complications is high.

This is why the medical treatment should be reconsidered as a first line therapy and before referral to a specialist, the LNG $\left(\mathrm{C}_{21} \mathrm{H}_{28} \mathrm{O}_{2}\right)$ - releasing IUS should be tried whenever there are no contraindications. Using LNG - releasing IUS (52 mg), the incidence of hysterectomy curettage, surgical sterilization, and oral contraceptives is lower [17-19].

LNG $\left(\mathrm{C}_{21} \mathrm{H}_{28} \mathrm{O}_{2}\right)$-releasing IUS $52 \mathrm{mg}$ and endometrial ablation represent two alternative and conservative methods to the hysterectomy in menorrhagia treatment.

The study aimed to compare the effectiveness of LNG $\left(\mathrm{C}_{21} \mathrm{H}_{28} \mathrm{O}_{2}\right)$-releasing IUS $52 \mathrm{mg}$, as a conservative method for perimenopausal bleeding control, compared to other conservative methods (hysteroscopy, endometrial ablation) and to hysterectomy. The main monitored parameters were the postoperative complications, the postoperative recovery, the catamenial characteristics and other symptoms, and also the satisfaction of patients treated after one, six and tw elve months.

\section{Experimental part}

Material and Methods

The subjects of this study were 270 women aged 35 to 49 , with heavy menstrual bleeding caused by different

*email: constantin_olaru@yahoo.com; nussbaumlaura@yahoo.com; vlader2000@yahoo.com 
pathological circumstances as endometrial hypertrophy, polyps, uterine fibroids, endocervical lesions, chronic endometritis, intrauterine device (IUD)-related pathology, congenital abnormalities.

The study was approved by the Ethics Committee of the Victor Babes University of Medicine and Pharmacy Timisoara, in accordance to the Helsinki Declaration and to some published models [20-26].

The study population was selected as to be eligible for both conservative treatment methods or hysterectomy (completed family size). They were divided in 3 groups taking into account the treatment method chosen for uterine bleeding control: Group A -hysterectomy; Group B -endometrial ablation; Group C - LNG $\left(\mathrm{C}_{21} \mathrm{H}_{28} \mathrm{O}_{2}\right)$ - releasing IUS $52 \mathrm{mg}$. Group B and Group C represent the conservative treatment groups.

The LNG-releasing IUS used in our study as an alternative conservative treatment has a steroid reservoir (hormone elastomer core) around the vertical stem (T-body polyethylene frame). The reservoir contains a total deposit of $52 \mathrm{mg}$ Levonorgestrel [(-)-13-Ethyl-17-hydroxy-18,19dinor-17 $\alpha$-pregn-4-en-20-yn-3-one], molecular weight 312.4], with an initial release rate of $20 \mu \mathrm{g} /$ day of Levonorgestrel. The reservoir is covered by a silicone (polydimethylsiloxane) membrane. The polyethylene frame contains barium sulfate, which makes it radiopaque. A monofilament brown polyethylene removal thread is attached to a loop at the end of the vertical stem of the Tbody.

Preoperative preparation consisted in administration of Diphereline (Triptorelin - $\mathrm{C}_{64} \mathrm{H}_{82} \mathrm{~N}_{18} \mathrm{O}_{13}$ ) or Danazol $\left(\mathrm{C}_{22} \mathrm{H}_{27} \mathrm{NO}_{2}\right)$ for 30 days in cases presenting with menstrual bleeding to reduce preoperative endocavitary blood supply for a better visualization throughout the procedure.

The fluid distension liquid used was the saline solution in case of VERSAPOINT bipolar electrode, or Ispirol (Mannitol - $\mathrm{C}_{6} \mathrm{H}_{14} \mathrm{O}_{6}+$ Glicocol - $\mathrm{C}_{2} \mathrm{H}_{5} \mathrm{NO}_{2}$ ) when a resectoscopy was performed, using an Olympus Resectoscope.

\section{Results and discussions}

Group A (hysterectomy) included patients with uterine pathology, such as uterine fibroids, endocervical lesions, endocervical lesions, adenomyosis, synechiae.

Group $B$ and $C$ included patients with endo-uterine pathology, such as polyps, uterine fibroids, glandular hyperplasia, except for 2 cases in which we used LNG-IUS in reductive purpose, as the patients had endometrium cancer, and other treatment was inadequate. Eighteen other patients underwent a hysteroscopy followed by the administration of an LNG-releasing IUS (52 mg).

At 6 months and after 1 year the situation was as indicated in (fig. 1.).

Women treated by surgical hysteroscopy (groups B and C) showed an improvement in morbidity indices and a significantly shorter recovery period than the hysterectomized ones (the average total recovery time: $21 \pm 7.4$ days compared to $60 \pm 10.5$ days, $P<0.0001$, ES).

Three weeks after the procedure time, $11 \%$ of the hysterectomized patients and $68 \%$ of the group with conservative surgery resumed sexual activity $(P<0.01$, FS). Also, $16 \%$ of group A and $80 \%$ of groups B and C were fully recovered [a $64 \%$ difference, $P<0.0001, E S$ ], $43 \%$ of patients had resumed work. These results are supported by similar published data $[7,8,13,14]$.

After 12 months from the procedure time, hysterectomy was performed in 12 other women from the groups $B$ and $C$, in 4 cases for continuing symptoms; in 8 cases the hysteroscopy procedure was repeated, 45 were amenorrhoeic or had only a brown leakage. In group C, 45 patients had hypomenorrhea and 35 amenorrhea after one year.

At 1 year, 86\% from group $A$ and $84 \%$ from groups $B$ and $C$ were very satisfied with the surgical effect, while $93 \%$ from group $B$ and $91 \%$ from group $A$ and $C$ said they had noticed a significant improvement in symptoms.

Our results seemed to be similarly as reported in many other published data [17-19, 26-33].

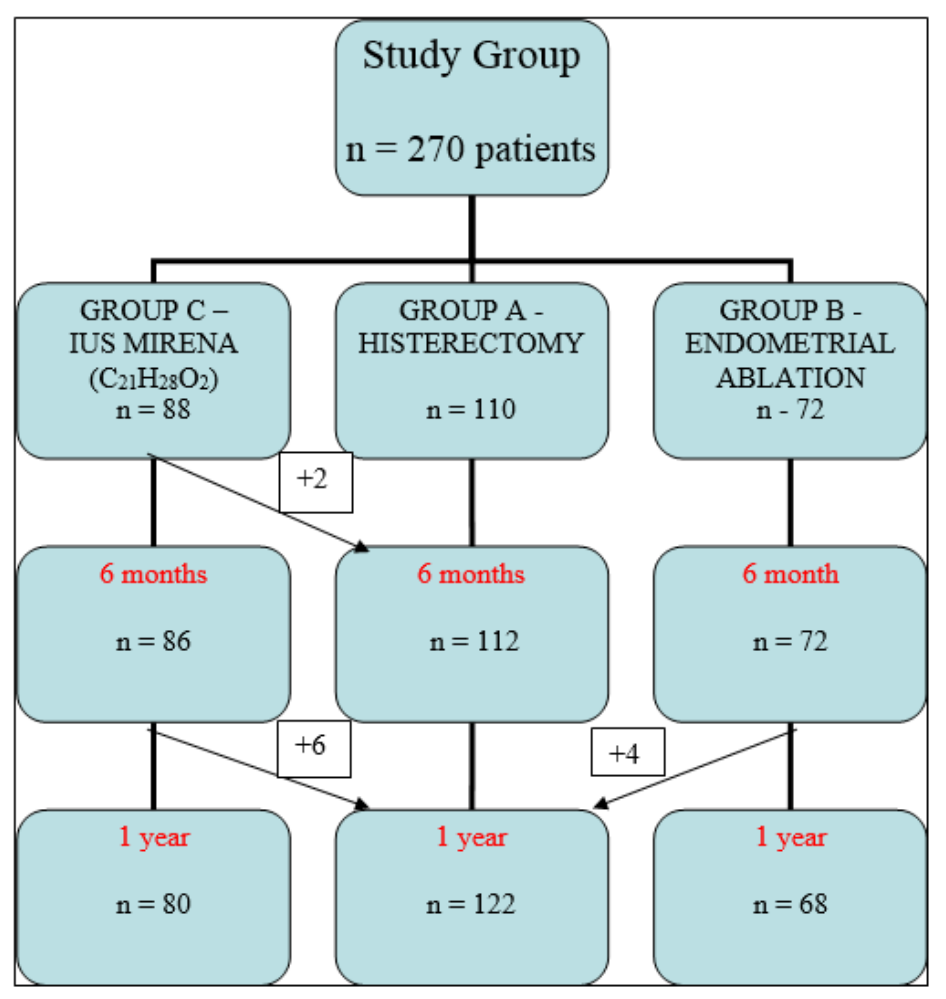

Fig. 1. The situation of the studied groups at 6 months and after 1 year 
We have also followed up the body weight, the hemoglobin $\left(\mathrm{C}_{2055} \mathrm{H}_{466} \mathrm{O}_{832} \mathrm{~N}_{812} \mathrm{~S}_{8} \mathrm{Fe}_{4}\right)$ and serum ferritin $[\mathrm{FeO}(\mathrm{OH})]_{0}\left[\mathrm{FeO}^{202}\left(\mathrm{H}_{2}^{464} \mathrm{O}_{3}^{832}\right]\right.$ levels, the serum follicle stimulating hormone ( $\mathrm{FSH})\left(\mathrm{C}_{79} \mathrm{H}_{125} \mathrm{~N}_{19} \mathrm{O}_{2} \mathrm{~S}\right)$ levels in the studied groups, at different time points: at baseline, after 6 months and / or after 12 months (figs. 2, 3 and.4).

We further evaluated the situation of the ovarian cysts, vaginal discharge and urinary problems were also monitored the studied groups (fig. 5, fig. 6 and table 1.)
There were no significant differences in results between the cases treated by VERSAPOINT bipolar system and the group treated by resectoscopy (using an Olympus Resectoscope). A difference was noticed only concerning a greater safety during surgery, related to the distension medium - saline solution versus glycine + glycol. Tur syndrome was avoided by using saline solution as a distension medium.

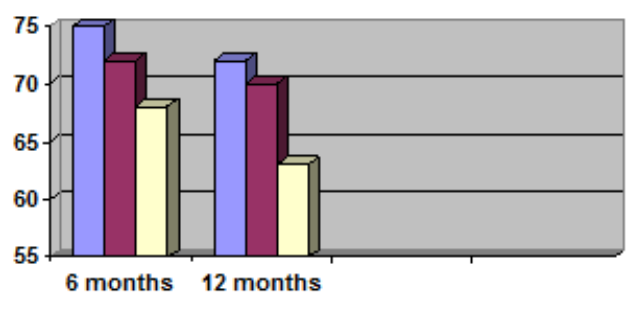

Fig. 2. The body weight evolution in the studied groups
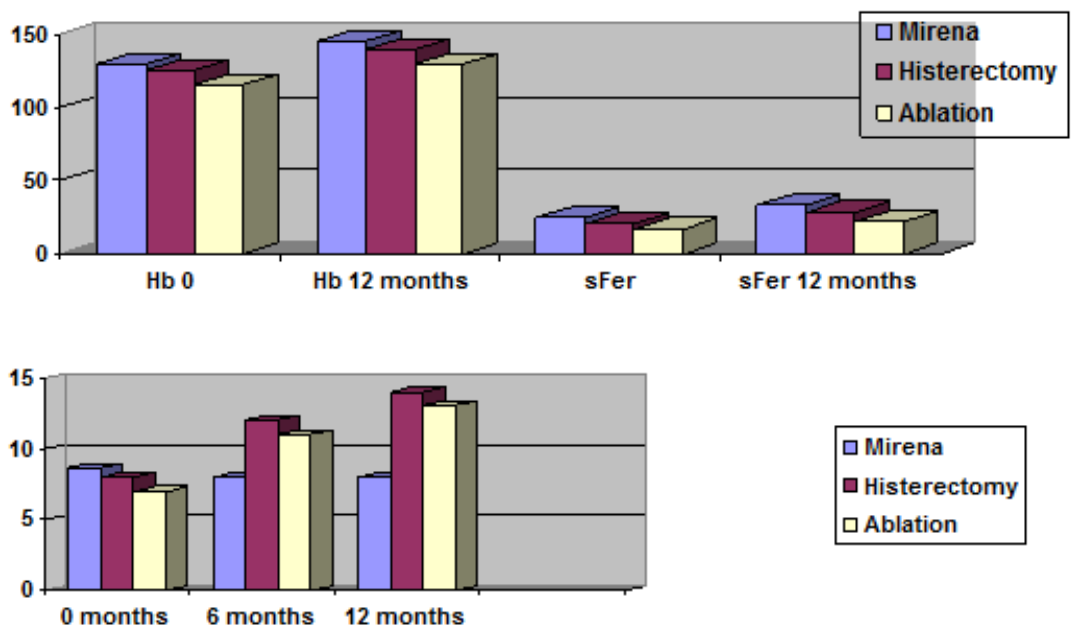

Fig. 3. Serum ferritin - $[\mathrm{FeO}(\mathrm{OH})]_{8}\left[\mathrm{FeO}\left(\mathrm{H}_{2} \mathrm{PO}_{4}\right)\right]$ [IU/L] and hemoglobin $\left(\mathrm{C}_{2052} \mathrm{H}_{4664} \mathrm{O}_{832} \mathrm{~N}_{8812} \mathrm{~S}_{8} \mathrm{Fe}_{4}\right)$ $[\mathrm{g} / \mathrm{L}]$ levels in the studied groups

Fig. 4. The follicle stimulating hormone (FSH) $\mathrm{C}_{79} \mathrm{H}_{125} \mathrm{~N}_{19} \mathrm{O}_{23} \mathrm{~S}[\mathrm{mUl} / \mathrm{mL}$ ] levels for the studied groups

Fig. 5. Ovarian cysts (\%) followed up in women from the studied groups

Fig. 6. The vaginal discharge (\%) in the studied groups

Table 1

ENCOUNTERED URINARY PROBLEMS IN THE STUDIED GROUPS

\section{Conclusions}

The hysteroscopy is the method of choice in diagnosis and therapeutic management of hemorrhagic metropathy cases.

The hysteroscopy performed surgery was superior to hysterectomy, taking into account the postoperative

complications and recovery, resumption of sexual activity and working.

The bipolar electrosurgical VERSAPOINT system is a safe and effective alternative in the treatment of intrauterine pathology. Our results allow us to mention the possibility of a surgery a few months after the hysteroscopy and 
endometrial ablation, and also the possibility of repeating the hysteroscopy procedure after a while, in some cases.

The LNG $\left(\mathrm{C}_{21} \mathrm{H}_{28} \mathrm{O}_{2}\right)$ - releasing intrauterine system proved to be effective in reducing metrorrhagia associated with endometrial dysplasia, uterine fibroids, polyps.

\section{References}

1.EMANUEL, M.H., WAMSTEKER, K., HART, et al, Obstet. Gynecol., 93, 1999, p. 8.

2.WAMSTEKER, K., DeBLOCK, S., Diagnostic Hysteroscopy: technique and documentation: WB Saunders, 1993, p. 76.

3.FOLESCU, R., ZAMFIR, C.L., SISU, A.M., MOTOC, A.G.M., ILIE, A.C., MOISE, M., Rom. J. Morphol. Embryol., 55, no. 3, 2014, p. 797.

4.GARUTI, G., CELLANI, F., COLLONELLI, M., et al, J. Am. Assoc. Gynecol. Laparosc., 11, no. 4, 2004, p. 4.

5.HOGEA, L.M., NUSSBAUM, L.A., CHIRIAC, D.V., AGEU, L.S., ANDREESCU, N.I., GRIGORAS, M.L., FOLESCU, R., BREDICAN, A.C., PUIU, M., RO'CA, E.C.I., SIMU, M.A., LEVAl, C.M., Rom. J. Morphol. Embryol., 58, no. 3, 2017, p. 767.

6.NUSSBAUM, L.A., OGODESCU, A., HOGEA, L.M., NUSSBAUM, L., ZETU, I., Rev. Cercet. Interv. Soc., 56, no. 1, 2017, p. 114.

7.STEVANOVIC, D., BAGHERI, Z., ATILOLA, O., VOSTANIS, P., STUPAR, D., MOREIRA, P., FRANIC, T., DAVIDOVIC, N., KNEZ, R., NIKSIC, A., DODIG-CURKOVIC, K., AVICENNA, M., MULTAZAM, NOOR, I., NUSSBAUM, L., DELIJ KOVIC, A., AZIZ, THABET, A., PETROV, P., UBALDE, D., MONTEIRO, L.A., RIBAS, R., Epidemiology and Psychiatric Sciences, 26, 2017, p. 430.

8.ROHAN, D., BUGGY, D.J., CROWLEY, S., et al, Can. J. Anaesth., 52, no. 2, 2005, p. 42.

9.LOTFALLAH, H., FARAG, K., HASSAN, I., et al, J. Reprod. Med., 50, no. 2, 2005, p. 7.

10.BETTOCCHI, S., CECl, O., NAPPI, L., et al, J. Am. Assoc. Gynecol. Laparosc., 11, no. 1, 2004, p. 59.

11.GUIDA, M., PELLICANO, M., ZULLO, F., et al, Hum. Reprod., 18, no. 4,2003, p. 3.

12.CLARK, T.J., KHAN, K.S., GUPTA, J.K., Eur. J. Obstet. Gynecol. Reprod. Biol., 103, no. 1, 2002, p. 7.

13.MUNRO, M.G., Practical Manual of Histeroscopy and Endometrial Ablation Techniques, Taylor \& Francis, London, 2004, p. 49.

14.VALLE, R.F., Operative hysteroscopy, Philadelphia, Lippincott, 1995, 35, p. 1.

15.GAVRIS, C., POROCH, V., SIMION, L., BARACAN, A., TOADER, E., PASCU, A.M., Rev. Chim. (Bucharest), 68, no. 7, 2017, p. 1586.

16.MOGA, M.A., IRIMIE, M., OANTA, A., PASCU, A., BURTEA, V., Asian Pacific Journal of Cancer Prevention, 15, no. 16, 2014, p. 6887. DOI: 10.7314/APJ CP.2014.15.16.6887.
17.RUIZ, J.M., NEUWIRTH, R.S., J. Gynecol. Surg., no. 8, 1992, p. 24. 18.NOVAK, E.R., WOODRUFF, J.D., Myoma and other benign tumours of uterus, WB Saunders, 1979, p. 79.

19.NEUWIRTH, R.S., Am. J. Obstet. Gynecol., 13, 1978, p. 4.

20.POROCH, V., AGHEORGHIESEI, D.T., Postmodern Openings, 9 , no. 2, 2018, p. 225.

21.ROGOZEA, L., REPANOVICl, A., CRISTEA, L., BARITZ, M., MICLAUS, R., PASCU, A., Proceedings of the 4th WSEAS/IASME International Conference on Educational Technologies (Edute'08), Book Series: Recent Advances in Computer Engineering, Corfu, Greece, 2008, Oct. 26-28, p. 87.

22.AGHEORGHIESEI CORODEANU, D.T., POROCH, V., 6th LUMEN International Conference on Rethinking Social Action Core Values, 16-19 April 2015, lasi, Romania, Rethinking Social Action. Core Values, p. 33.

23.BALAN, G.G., TRIFAN, A., SAVIN, C., BALAN, A., GOLOGAN, E., Revista de Cercetare si Interventie Sociala, 55, 2016, p. 244.

24.SAVIN, C., TOADER, E., BALAN, G.G., GAVRILA, L.M., BALAN, A.. Revista de Cercetare si Interventie Sociala, 54, 2016, p. 156.

25.HOGEA, L.M., HOGEA, B.G., NUSSBAUM, L.A., GRIGORAS, L.M., ANDOR, B.C., LEVAI, C.M., BREDICEAN, A.C., Rom. J. Morphol. Embryol., 58, no. 1, 2017, p. 175.

26.TOADER, E., BALAN, G.G., ILIESCU, D.B., PERJU-DUMBRAVA, D., Romanian Journal of Legal Medicine, 25, no. 1, 2017, p.125.

27.NUSSBAUM, L.A., HOGEA, L.M., CHIRIAC, D.V., GRIGORAS, M.L., FOLESCU, R., BREDICEAN, A.C., ROSCA, E.C.I., MUNCAN, B., NUSSBAUM, L.M., SIMU, M. LEVAI, C.M., Rom. J. Morphol. Embryol., 58, no. 4, 2017, p. 1435.

28.CHIRIAC, D.V., HOGEA L.M., BREDICEAN, A.C., REDNIC, R., NUSSBAUM, L.A., HOGEA, G.B., GRIGORAS, M.L., J. Morphol. Embryol, 58, no. 3, 2007, p. 1023.

29.HOGEA, L.M., TUTA SAS, I., POROCH, V., NUSSBAUM, L.A., SAS, I., SERBAN, D., ERDELEAN, D., FOLESCU, R., ZAMFIR, C.L., BREDICEAN, C.A., SIMU, M.A., Rev. Chim. (Bucharest), 69, no. 4, 2018, p. 934. 30.MIOC, M., AVRAM, S., TOMESCU, A.B., Rev. Chim. (Bucharest), 68, no. 3, 2017, p. 500.

31.BALASA, R.I., SIMU, M., VOIDAZAN, S., BARCUTEAN, L.I., BAJKO, Z., HUTANU, A., SIMU, I., MAIER, S., CNS \& Neurological DisordersDrug Targets, 16, no. 9, 2017, p. 1018.

32.POPESCU, S., TIMAR, B., BADERCA, F., SIMU, M., DIACONU, L., VELEA, I., TIMAR T., Clinical Interventions In Aging, 11, 2015, p. 313. 33.OANCEA, R., PODARIU, A.C., VASILE, L., SAVA-ROSIANU, R., FOLESCU, R., Rom. J. Morphol. Embryol., 54, no. 2, 2013, p. 333.

$\overline{\text { Manuscript received:4.09.2018 }}$ 